\title{
The Effectiveness of Buddy Support System Implementation among Science Teachers: The Case of Malaysia
}

\author{
Dr. Abdul Ghani Kanesan Abdullah \\ School Educational Studies Universiti Sains Malaysia \\ 11800, Pulau Pinang Malaysia \\ Tel: 60-4-653-3888Ｅ-mail: agk@usm.my \\ Dr. Naser Jamil Ali Alzaidiyeen \\ School Educational Studies Universiti Sains Malaysia \\ 11800, Pulau Pinang Malaysia \\ Tel: 60-1-2498-9384_E-mail: naser_jamel@yahoo.com \\ Dr. Rattana Seedee \\ Lampang Rajabhat University Thailand \\ Tel: 66-83-653-2173 E-mail: r_seedee@yahoo.com
}

\begin{abstract}
The biggest challenge that is being faced by the Malaysian Education scenario occurred when shifting of the Malaysia's National Science Curriculum from the use of Malay language to English as the medium of instruction. Analogically, varied steps and measures were being put into action to sufficiently groom the available teachers towards fulfilling the challenges. One of the programs is Buddy Support System that was aimed as a peer support system or program to apprehend and provide the necessary avenue for the science teachers to adequately equip themselves towards competency in teaching of science. Therefore this study aims at identifying the effectiveness of professional development among the science teachers in Malaysia under the implementation of the Buddy System in secondary school teachers. A total of 480 science teachers were randomly selected from 160 secondary schools throughout the Northern part of Peninsular Malaysia. Data were collected using questionnaires adapted from Lee (2006) to measure the management of the Buddy System Program. Meanwhile, the effectiveness of the Buddy Support Program was measured using questionnaires from Isa (2000). The findings of the study indicate that the level of management and impact of the implementation on the Buddy System Program in general are at the mediocre level. Apart from that, a positive relation and significant $(r=0.73 ; p<0.05)$ correlation was found between the perceived effectiveness of the Buddy System Program and the management of the implementation of the Buddy System Program. Besides, the findings also denote the existence of significant influence between the readiness, training, application and consolidation upon the perceived effectiveness of the Buddy System Program in Malaysia.
\end{abstract}

Keywords: Effectiveness, Buddy Support System, Science teachers

\section{Introduction}

Various programs such as Computer in Education, Learning of Science and Mathematics in English language, Pilot Project of Smart Schools, Computer Literacy Development Program, usage of Abacus in primary school and other program had brought in changes in the Malaysian education scene. Thus, it evolves a great impact on teacher professional development programs from Malaysian Education Ministry to schools in general. This is due to the importance of ensuring that the teachers are up to par in a pertinent quality to the effort to improve and develop the students' achievement (Ministry of Education Malaysia, 2006).

In relation to this, Ministry of Education Malaysia and the States Education Departments has distributed a large sum of allocations from their annual spending towards training of teachers nationwide, for example, according to Kedah State Education Department's Financial Performance and Implementation of Program Report indicates that 
a total of RM2.082 million was allocated for Teachers In-Service Training Programs in 2006 with 232 programs. Out of these, a total of $57.76 \%$ was spending on training the teachers of science and mathematics. Meanwhile, for the year 2005, Kedah State Education Department had trained 8555 teachers under the professional development program such as Teaching of Mathematics and Science in English (ETeMS) courses, Science and Mathematics Curriculum Orientation Courses (KOSM), Teachers English Proficiency and Competency Development Courses, Abacus Courses and others (EDOK, 2006).

The professional development programs implemented by the Ministry and state departments were delegated to the school administration to expand at the school level through the existing schools in-service training mechanism or the subject departments of the schools (Lee, 2006). Thus, if a teacher faces any problems or difficulties, the school principal and subordinates relevantly acts as the reference through a special program system. In relation to this, the implementation of Buddy System Program is significantly an important program that schools need to implement as one of the most professional development programs. Even though, the evaluation of the effectiveness of programs and courses that were conducted or carried out seem not to give much importance to the aspect related to teachers' professional development (Lee, 2006). Moreover, most teachers were found to be less interested or believe that the professional development programs are of burden and were of time (Vijayaletchimi, 2006). Additionally, based on researches by Hassan (2005) and Ibrahim (2005) found that the implementation of professional development programs is low level.

\section{Professional Development Program}

Ministry of Education Malaysia (1995) defines the professional development programs as programs that aim at providing training with the purpose of developing the performance of an individual in the aspect related to his/her career. In other word, wider in scope, they include all types of training which nurture the wellbeing of an individual that indirectly contributes towards the performance of his or her job or work. These programs are planned by the management with the principle of upgrading and developing the excellence and achievement of the organization's aim. Professional Development Program is a an experience based on learning and personal knowledge within the people related to the education circle that is shared with the rationale of developing and cultivating high work spirit and motivation which lead towards job satisfaction (Isa, 2000; Blackwell \& Blacmore, 2003).

It is evident that professional development programs are processes or activities that are developed or designed towards enhancing knowledge, skills and teacher quality with the aim of school excellence. In relation to this, Sin (2004) suggested that the role of the Resource Centre need to be heightened, programs to be parallel with the Ministry of Education and State Education Department, arrangements of meetings should be prone towards 'developmental', inviting external lecturers and speakers, existence of Group Work Quality Development Day, importance in regards to writing of attending minutes and Buddy System Concepts in order to make positive progressiveness of the schools' teacher professional development programs.

\section{Buddy Support System}

Buddy Support System is a program created in schools to support the implementation of Teaching and Learning of Science and Mathematics in English in collaborative with the process of motivating the learning among teachers (Ibrahim, 2005). In this program, a group of teachers will facilitate as resource teachers or known as critical friend to teacher that requires assistance to overcoming problems related English language (Education Department of Kedah, 2006). Those critical friends or guiding teachers should be competent, proficient and skilled in English language. These teachers might be science, mathematics or English teachers but the clear aspect is that it should be an individual acts as a reference for the Science, Mathematics and English teachers in the school. Guiding teachers or the critical friends must possess personality traits that are conducive to others, easy to be contacted, jovial, responsible and sincere, with moral values and patience. A guiding teacher or an expert that acts as the buddy support in this program is considered to be a guiding force that also provides support and challenges to their colleagues.

The advantages of this program according to the Ministry of Education are as follows: (1) to enhance the English language skills of the science and mathematics teachers; (2) to develop the interpersonal skill, the ability to communicate, give response and management aptitude amongst the science and mathematics teachers; (3) to give exposure of resources and teaching aids that was provided and supplied towards the purpose of teaching and learning; (4) to assist teachers of science and mathematics that require support from the perspective of language, pedagogical knowledge, psychological and emotional implementation of ETeMS; (5) to create the collaborative learning practices and autonomous and self learning among teachers of science and mathematics; and (6) to promote the 'self help' principles among the teachers with expertise available in the school. 


\section{Teacher Professional Development Model}

In the process of ensuring the effectiveness of teacher professional development program at schools, it has to be implemented systematically. Varied models can be considered when looking into the effectiveness of the professional development program. Such models are Sarch's (2003) Staff Development for School Improvement Model, RPTIM Staff Development Model (Readiness, Planning, Training, Implementation and Maintenance) by Woods (1982) and Teacher Training success Model by Teacher Training Unit, Ministry of Education Malaysia (1996). Based on the literature review and recommendations from previous researches, this study selected the RPTIM Staff Development Model which had been advocated by Woods (1982). Wood (1982) promoted RPTIM Staff Development Model (Readiness, Planning, Training, Implementation and Maintenance) for effective planning and implementations. This model is a process that acknowledges design of education based on researches in the systematic and comprehensive service orientation. Moreover, this model identifies what happens before, during, and after the program and training being implemented.

\section{Purpose of This Study}

Based on the above premises, this study aims to identify:

a. The effectiveness level of science teachers professional development program under the implementation of Buddy Support System from the aspect related to management, studied to the readiness, planning, training, application and consolidation dimension.

b. The effective impact of the program in the professional development program of science teacher under the implementation of Buddy Support System from the reaction, learning and attitude index.

c. The relation between aspects of management consisting of readiness, planning, training, application and consolidation with the effectiveness of Buddy Support System program, and

d. The influences of variables in a pertinent management aspect upon the effectiveness of Buddy Support System program.

\section{Research Methodology}

A Total of 480 science teachers from secondary schools were selected randomly from the group of 1716 teacher attending the ETeMS course conducted by the Kedah State Education Department (one of the 13 state in Malaysia). Data from the respondents were acquired through the use questionnaires distributed to the mentioned teachers through their respective principals. A 26 items adapted from Lee (2006) who used in measuring the management of the Buddy System Program. This questionnaire was divided into five dimensions ranging from the management professionalism development program under the scope of readiness, planning, training, application and consolidation. Meanwhile, the effectiveness of the Buddy Support Program was measured through the utilization of 15 item questionnaires from Isa (2000) to identify three pointers namely, reaction, learning and the change of attitude. The response was evaluated using five Likert Scale. The collected data were then analyzed using Statistical Package for the Social Sciences (SPSS) software version 14.0.

\section{The Findings and Results}

\subsection{Implementation of Buddy Support System}

The implementation of Buddy Support System from the aspect of management was analyzed based on scientific descriptive involving mean score and standard deviation. The findings as shown in the table 1.0 below describe a high result in the management aspect like readiness (mean $=3.34)$, planning $($ mean $=3.51)$, training $($ mean $=3.29)$, application $($ mean $=3.21)$ and consolidation $($ mean $=3.19)$ with mediocre mean score on aspect of training and mediocre mean score with application. Overall mean from the management aspect of Buddy Support System program is 3.67 and this result indicates that, in overall the aspect of management of the Buddy Support System standing in an average and mediocre level only.

\subsection{Impact of the Effective Implementation of Buddy Support System}

The implementation of Buddy Support System from the aspect related to effectiveness was analyzed based on scientific descriptive and the interpretations were determined in relation to establishment by Foo and Teng (2002) as shown in Table 2.0 below:

Meanwhile, Table 3.0 shows the finding of the mean score from three aspect mainly researched which are reaction $($ mean $=3.24)$, learning $($ mean $=3.27)$ and attitude $($ mean $=2.71)$. It was found that reaction and learning show impact of the Buddy Support System from an average standing with high mean score. Whereas, aspect of attitude is found to be low in impact. In addition to this, the overall mean score of the impact of implementation of Buddy 
Support System is merely 3.07. This indicates that in total, the impact of the implementation of the effectiveness of the Buddy Support System is only at mediocre level.

\subsection{Relationship between Management Aspects with the Perceived Effectiveness of Buddy Support System}

The findings in table 4.0 shows that there is a concrete positive relationship and significance $(r=0.73 ; p=<0.05)$ between the perceived effectiveness of the Buddy Support System with the management of the implementation of the Buddy Support System.

Further analysis points to the existence of positive concrete relationship between the perceived effectiveness of the program with the dimensions of readiness $(r=0.63 ; \mathrm{p}<0.05)$, $\operatorname{training}(\mathrm{r}=0.66 ; \mathrm{p}<0.05)$, application $(\mathrm{r}=0.71 ; \mathrm{p}<0.05)$ and consolidation $(\mathrm{r}=0.67 ; \mathrm{p}<0.05)$. Meanwhile, with the planning dimension, an average positive concrete relations is found to be in existence whereby $(\mathrm{r}=0.56$; $\mathrm{p}<0.05)$.

In overall, the concrete positive relationship is shown by the entire researched dimension which are readiness $(\mathrm{r}=$ $0.82 ; \mathrm{p}<0.05)$, planning $(\mathrm{r}=0.88 ; \mathrm{p}<0.05)$, training $(\mathrm{r}=0.92 ; \mathrm{p}<0.05)$, application $(\mathrm{r}=0.92 ; \mathrm{p}<0.05)$, and consolidation $(\mathrm{r}=0.90 ; \mathrm{p}<0.05)$ on the overall management aspects of Buddy Support System. Whereas, concrete positive indicated between the dimensions of readiness and planning $(\mathrm{r}=0.66 ; \mathrm{p}<0.05)$, training $(\mathrm{r}=0.66 ; \mathrm{p}<0.05)$, application $(\mathrm{r}=0.75 ; \mathrm{p}<0.05)$ and consolidation $(\mathrm{r}=0.69 ; \mathrm{p}<0.05)$. As for the relationship of training with application dimension, there is a clear concrete positive indication $(\mathrm{r}=0.83 ; \mathrm{p}<0.05)$. Meanwhile, the positive relationship shown between training and consolidation is $(r=0.79 ; p<0.05)$. Finally, the positive relationship shown between the dimension of application and consolidation is through $\mathrm{r}=0.83$ for $\mathrm{p}<0.05$.

\subsection{Repercussion of Management Aspect towards Effectiveness of Buddy Support System}

Effects of management aspects; readiness, planning, training, application and consolidation with the perceived effectiveness of Buddy Support System was analyzed through the regression analysis as shown in Table 5.0 below :

The regression analysis indicates that $56.1 \%$ variation or changes on the variant of Buddy Support System program effectiveness are contributed by management aspects. Meanwhile, management aspect such as readiness $(\beta=0.19$; $\mathrm{p}<0.05)$, training $(\beta=0.16 ; \mathrm{p}<0.05)$ application $(\beta=0.35 ; \mathrm{p}<0.05$ and consolidation $(\beta=0.17 ; \mathrm{p}<0.05)$ have significantly influences towards the effectiveness of the Buddy Support System. Thus, it can be concluded that the management of application is the aspect that has the highest level of influence towards the effectiveness of Buddy Support System.

\section{Discussion and Research Implication}

The findings of the study support the findings of Vijayaletchmi (2006), Ibrahim (2005) and Isa (2000) found the effective management of internal training from the dimension of readiness, planning, training, application and consolidation are of high level. Meanwhile, the analysis upon the indicating aspects of reaction, learning and attitude were found to have relevantly high impact towards the effectiveness of implementation of the Buddy Support System. In addition, the findings of the study also indicate that there are in existence a positive and significant relationship between perceived effectiveness and management of Buddy Support system. These results sustain relevantly with researches Shaharuddin (1998), Isa (2000), Sharifah (2004) and Lee (2006). They recommend that the management's aspect of program has vital relationship in ensuring the effectiveness of professional development program.

The implications of this study to the administrators are that they need to take into consideration the responses from the teachers as one of the input of professional development program. The findings of this study need to be focused by the administrators for the enhancement of teacher quality through Buddy Support System. The awareness of the importance towards the need of individual, group or school will direct the seriousness of the administrators in generating the ideas from teachers. In matter of fact, based on the findings of the study, there is a clear manifestation that the effectiveness of the Buddy Support System has a pertinent relationship with the management program. As more of the management aspect is given prominence, coherently the effectiveness of program also heightens.

Therefore, the District Education Office, State Education Department and The Ministry of Education should give prior emphasis pertaining to the management of programs in order to ensure the effectiveness of the implemented programs as it coincides with the findings of the study that indicates existence of positive concrete relationship which is significant between the perceived effectiveness in relation to the management of the Buddy Support System program. Finally, the findings of the study provide the implication that, RPTIM Model used by the researcher is appropriate and suitable to utilize in order to identify the professional development of teacher in the aspect of program management conducted in schools. 


\section{Conclusion}

The study proves that peer support training through the implementation of Buddy Support Program should be carried out continuously with emphasis given upon the management aspects in the process towards upgrading to develop the effectiveness of Buddy Support System programs in school. The Peer Support facilitators and teachers of science and mathematics ought to understand thoroughly the implementing guidelines of Buddy Support System underlined by the Teacher Education Division. In addition, Buddy Support System Training Module need to be produced at school level as to ensure the peer support facilitator has the activity guide that is appropriate to be executed in schools. This module is presumably adaptive with the actual need of the schools with concise focus on the aspects pertaining to language, utilization of language support courseware and teaching courseware.

\section{References}

Blackwell, R. \& Blacmore, P. (2003). Towards Strategic Staff Development in Higher Education. Berkshire: Open University Press.

Education Department of Kedah (EDOK). (2006). Buddy Support System Implementation Manual 2006. Alor Star.

Foo, S. F., \& Teng, L. K. (2002). Persepsi Guru Terhadap Penerapan Nilai-nilai Murni Dalam Kepimpinan Pengetua Sekolah-sekolah Menengah Bahagian Sri Aman, Sarawak. Educational Policy and Research Development, 4, 53-64.

Hassan. S. (2005). Perubahan Terancang Dalam Pendidikan: Proses dan Mekanisme Pelaksanaa. Journal of Educational Leadership and Management, Institute of Aminuddin Baki, Pahang. 14(1), 1-17.

Ibrahim, O. K. (2005). Implementation of Buddy Support System in Kulim District. Prosiding Malaysian PPSMI Seminar 2005. Organized by Malaysian Ministry of Education, November 11-4, Kuala Lumpur.

Isa, R. (2000). In-house Training Management and Its Effectiveness Among Secondary Teachers in Kota Setar District of Kedah. Unpublished Master's Thesis. Universiti Utara Malaysia.

Lee, L. Z. (2006). Effectiveness of In House Training in Penangs' Secondary Schools. Unpublished Master's Thesis. Universiti Sains Malaysia, Penang.

Ministry of Education Malaysia. (1995). Ucapan Perutusan Tahun Baru 2006 Menteri Pelajaran Malaysia. [Online] Available: http//www.moe.gov.my/2006_01 17_Perutusana.pdf. (May 2008).

Ministry of Education Malaysia. (1996). Monitoring and Evaluation Module for In Service Courses. Kuala Lumpur. Teacher Educational Department.

Ministry of Education Malaysia. (2006). Nine Malaysian Plan 2006-2010. Putrajaya.

Mohd-Radzi A. (1995). Keberkesanan Latihan Dalaman: Satu Kajian Di Sekolah-sekolah Menengah Negeri Perak. UKM.Tesis Sarjana Pendidikan Yang Tidak Diterbitkan.

Sarch, J. (2003). Professionalism, perfomativity and Empowerment: Discourses in the politics, policies and purposes of Continuing Professional Development. Berkshire: Open University Press.

Shaharuddin, S. (1998). Effectiveness of In House Training Management. Unpublished Masters' Thesis. Universiti Sains Malaysia, Penang.

Sharifah. M. (2004). Hala Tuju Pengajaran dan Pembelajaran Sains dan Matematik Dalam Bahasa Inggeris. Digest Education, 4(1), 1-12.

Sin. I. (2004). What is Effective Principals' Traits, Behavior and Action? Journal of Educational Leadership and Management, Institute of Aminuddin Baki, Pahang, 14(1), 1-17.

Vijayalatchumi V. (2006). Staff Development Program in School and Teacher Quality. Unpublished Masters' Thesis. Universiti Sains Malaysia-Penang.

Wood, F.H. (1982). Practitioners and Professors Agree On Effective Development Practice. Journal Educational Leadership, 11(4), 28-31. 
Table 1. Interpretation of Buddy Support System Management Level

\begin{tabular}{|l|c|c|c|}
\hline Management Aspect & Mean & Standard Deviation & Interpretation of Practice Level \\
\hline 1. Readiness & 3.44 & 0.58 & Mediocre \\
\hline 2. Planning & 3.49 & 0.70 & Mediocre \\
\hline 3. Training & 3.29 & 0.72 & Mediocre \\
\hline 4. Application & 3.49 & 0.65 & Mediocre \\
\hline 5. Consolidation & 3.19 & 0.72 & Mediocre \\
\hline 6. Overall Management & 3.38 & 0.60 & Mediocre \\
\hline
\end{tabular}

Table 2. Interpretation of Mean Score $(\mu)$ For Buddy Support System Effectiveness Level

\begin{tabular}{|c|c|}
\hline Mean Score & Interpretation \\
\hline$\mu \leq 1.5$ & Provides impact at very low level \\
\hline $1.5<\mu \leq 2.5$ & Provides impact at low level \\
\hline $2.5<\mu \leq 3.5$ & Provides impact at mediocre level \\
\hline $3.5<\mu \leq 4.5$ & Provides impact at high level \\
\hline$\mu>4.5$ & Provides impact at very high level \\
\hline
\end{tabular}

Table 3. Level of Effectiveness of Buddy Support System Program

\begin{tabular}{|c|c|c|c|}
\hline Aspects & Mean & Standard Deviation & Interpretation of the Impact Level \\
\hline Reaction & 3.24 & 0.71 & Mediocre \\
\hline Learning & 3.27 & 0.78 & Mediocre \\
\hline Action & 2.71 & 0.75 & Mediocre \\
\hline Overall Effectiveness & 3.07 & 0.71 & Mediocre \\
\hline
\end{tabular}

Table 4. Pearson Correlation between Management Aspect and Overall Effectiveness of Buddy Support System Program

\begin{tabular}{|c|c|c|c|c|c|c|c|}
\hline & 1 & 2 & 3 & 4 & 5 & 6 & 7 \\
\hline 1. Overall Effectiveness & - & & & & & & \\
\hline 1. Readiness & $0.63(* *)$ & & & & & & \\
\hline 2. Planning & $0.56\left(^{* *}\right)$ & $0.66(* *)$ & & & & & \\
\hline 3. Training & $0.66\left(^{* *}\right)$ & $0.66(* *)$ & $0.77(* *)$ & & & & \\
\hline 4. Application & $0.71(* *)$ & $0.69(* *)$ & $0.75(* *)$ & $0.83(* *)$ & & & \\
\hline 5. Consolidation & $0.67(* *)$ & $0.67(* *)$ & $0.69(* *)$ & $0.79(* *)$ & $0.83(* *)$ & & \\
\hline 7. Overall . Management & $0.73(* *)$ & $0.82(* *)$ & $0.88(* *)$ & $0.92(* *)$ & $0.92(* *)$ & $0.90(* *)$ & \\
\hline
\end{tabular}

$(* *)$ sig. at $\mathrm{p}<0.05$ 
Table 5. Regression Analysis Results

\begin{tabular}{|l|c|c|c|c|}
\hline \multicolumn{1}{|c|}{ Variable } & B & Beta & T value & Sig \\
\hline Readiness & 0.24 & 0.19 & 4.12 & $0.00^{*}$ \\
\hline Planning & -0.06 & -0.06 & -1.22 & 0.22 \\
\hline Training & 0.17 & 0.16 & 2.75 & $0.01^{*}$ \\
\hline Application & 0.39 & 0.35 & 2.55 & $0.00^{*}$ \\
\hline Consolidation & 0.17 & 0.17 & $0.01 *$ \\
\hline $\begin{array}{l}\mathrm{R}^{2}=0.561 ; \text { Adjusted R } \mathrm{R}^{2}=0.556 \\
\text { F value }=121.108, \quad \mathrm{Sig}=0.00\end{array}$ & & \\
\end{tabular}

* Sig. at $p<0.05$ 